\title{
The rethinking and enhancement of the natural and cultural heritage of the cultural landscapes: the case of Sečovlje and Janubio saltpans
}

\author{
Luis Gregorio Abad Espinoza*
}

University of Milan-Bicocca (Itália)

\begin{abstract}
Cultural landscapes represent a complex category where the nature-culture dichotomy seem to not be able to unfold the main features and the profound relations that humans have with the environment. Drawing on ethnographic data collected in the saltpans of Sečovlje (Slovene Istria) and Janubio (Lanzarote-Canary Islands) this article examines informant's perceptions about the awareness of the importance and the enhancement of the holistic values of both saltpans, as well as the impacts and benefits of tourism. Comparing these perceptions about both cultural landscapes, I try to suggest that the complex fruitfully relations between humans and nature in these saltpans are at odds with the neoliberal logic of nature which exploit and commoditize its resources depriving them of their respective agency. A sustainability to contrast the harmful activities of the market ought to be understood not as a simply isolation and fencing of nature for the sake of conservation, but as a preservation that need to foster the continuity of the deep interactions between human culture and non-human nature which are the core of the cultural landscapes.
\end{abstract}

Keywords: Cultural landscapes; Sečovlje saltpans; Janubio saltpans; Culture-nature relations; Enhancement of the values.

El replanteamiento y la mejora del patrimonio natural y cultural de los paisajes culturales: el caso de Sečovlje y Janubio saltpans

Resumen: Los paisajes culturales representan una categoría compleja en la que la dicotomía naturaleza-cultura parece no poder desplegar las características principales y las relaciones profundas que los humanos tienen con el medio ambiente. A partir de los datos etnográficos recopilados en las salinas de Sečovlje (Istria eslovena) y Janubio (Islas Canarias, Lanzarote), este artículo examina las percepciones de los informantes sobre la conciencia de la importancia y la mejora de los valores holísticos de ambas salinas, así como la Impactos y beneficios del turismo. Al comparar estas percepciones sobre ambos paisajes culturales, trato de sugerir que las complejas relaciones fructíferas entre los seres humanos y la naturaleza en estas salinas están en desacuerdo con la lógica neoliberal de la naturaleza que explota y comercializa sus recursos privándolos de su agencia respectiva. Una sostenibilidad para contrastar las actividades dañinas del mercado debe entenderse no como un simple aislamiento y cercado de la naturaleza en aras de la conservación, sino como una preservación que debe fomentar la continuidad de las interacciones profundas entre la cultura humana y la no humana. Naturaleza que son el núcleo de los paisajes culturales.

Palabras Clave: paisajes culturales; Salinas de Sečovlje; Salinas de Janubio; Relaciones cultura-naturaleza; Mejora de los valores.

\section{Society and nature a trivial dichotomy or a complex relationship?}

Since the beginning of mankind people usually moved to different parts of the world to look for shelter, food and mostly explore the unknown. Indeed, the human being has been able to put the roots in every territory and landscape which they transformed and adapted to survive or in the words of Ellen

University of Milan-Bicocca (Itália); E-mail: l.abadespinoza@campus.unimib.it 
(1996) utilizing nature, by transforming and assimilating it into culture. Be that as it may, it seems that almost all ecosystems and landscapes around the world have been influenced or even "domesticated" by humans (Kareiva et al., 2007), however, this kind of domestication of the environment it is to be understood not only in utilitaristic Marxian terms as the historical materialism or human praxis in nature (Marx, 1994), where the latter is only a mean to subdue and extract its resources for the sake of the so called positivistic/evolutionistic development which has characterized the western "civilizing enterprise" of the industrial revolution up to now. On the contrary the natural environment has always played an important role for every society around the world, not only as a mere passive object to take advantage of its resources, but mostly for the meaning that different cultures attached to it, creating profound relations with the natural world that shaped their cosmologies, rituals, social structures, namely the way of "dwelling" and "being in the world" (Heidegger, 1962,1971), or the different ontologies which are the essential features of human nature. It is this kind of interactions and relations that each culture has with its own nature, which can be regarded as one of the most important issues in our own contemporary society.

Due to the environmental problems, fostered by the neoliberal machine which indiscriminately imposes its own logic of nature everywhere, these are development, exploitation and destruction of the natural environment, that the importance of the traditional practices and engagement with the nature that some communities have been maintaining until these days still represent the moral values which evidently contrast the harming activities of the neoliberal market and its own never-ending logic of development. For these people, nature is more than a thing to observe, measure and quantify or better to sell and buy as a mere commodity in the market, therefore the stark cartesian-western dualism of culture and nature is incapable to understand the very complex interplay that exists between these two categories. Nature and culture often cannot be resolved into a single dichotomy (Strathern, 1980), for this reason a somewhat radical western naturalistic ontology hinder us to better understand and explore the deep engagement and relations that some societies even in the "developed and modern" west have with their natural environment and how important are the conceptions of nature and its practices of environmental interactions (Ingold, 1992) to provide a different alternatives of thinking about the nature and its importance for all living and non-living beings.

Needless to say, the people who are used to dwell and live in natural environments such as the cultural landscapes and its traditional activities which I will treat in this article, have different conceptualizations of the nature in which they interact and perceive in their everyday lives. For them, as I argued above natural environment is not a mere brute fact, as the philosopher John Searle points out when he refers to the objects or reality independent of human consciousness (Searle, 1995). This kind of materiality and opacity of the nature it is not to be understood in isolation and devoid with meaning and values that each society endow it, as Descola (1992) perfectly explains: "the principles of the construction of social reality are primarily to be sought in the relations between human beings and their natural environment". Indeed, nature is the place where the mental and the material (Godelier, 1984) collide and conjoin each other forming a constant interaction where one of the most important aims is the equilibrium of the entire ecosystem, moreover these are the deep relations with the environment which most traditional and decentralized social systems have used to deploy so far, in fact they tended to develop means of regulating local ecosystems which were better geared to sustainability than modern economics (Rappaport, 1968, 1979).

Nevertheless, sustainability in a strict sense of term of the western Eurocentric conception of protection and conservation of the environment is a merely chimera, thus usually nature is treated as a mere piece of museum to protect and encapsulate in the time for the only purpose to maintain a virgin or pristine untouchable nature with no human interaction. However, I think this is the somewhat naturalistic western paradox, whence on one hand the ontological separated domain of nature is only a wild object that must be dominated and transformed by human culture and economic rationality, on the other, nature must be protected and maintained in a state of purity and wilderness without human action, hence any human impact and activity although harmless must be regarded as a threat for the preservation of the virgin nature. Thus, in either cases the culture-nature dualism is strikingly evident and could be understood in the metaphoric terms of human exploitation in the former and human contemplation in the latter.

It is this dichotomy between culture and nature that need to be challenged to attain a better scrutiny in the complex relations which exists among humans and non-humans, that is the characteristic complexity of the whole nature and its living and non-living beings. In the last decades, ecological anthropology has showed that most of the so called tribal or traditional societies around the world deploy different 
conceptualizations of nature and therefore the western dualism cannot apply for them (see, for example, Reichel-Dolmatoff, 1971; Seeger, 1981; Karim, 1981; Howell, 1984, Århem, 1990 and Descola, 1994). In this respect, it could be argued that only these societies have different conceptions of nature and the western dualism it is to be applied only in the west? Or to put it different, could be diverse conceptions of nature applied in the western cultural landscapes? The relations between local communities and the environment of these landscapes are more complex than a trivial western dichotomy? These questions I will try to answer in this article, analysing and comparing the saltpans and cultural landscapes of Sečovlje (Slovene Istria) and Janubio (Lanzarote-Canary Islands) to demonstrate that these western cultural landscapes represent a holistic interaction between humans and their environment, where the traditional activities of salt harvesting are still being maintained nonetheless the neoliberal activities of industrial salt production and mass tourism.

An ecological approach in anthropology will not neglect the complex interactions that these communities of salt workers have with the natural environment of the saltpans and moreover what different actors such as tourists and stakeholders of both territories think about the awareness of the importance of these values. This obviously emphasize that nature is not passive at all even in a western context, whereby it could be said that nature may be good to think (Lévi -Strauss, 1962) or as Descola (1992) points out a nature that may be good to socialize. Thus, cultural landscapes in this sense show how nature is also good to dwell, live and interact, such as the manifold activities which are still practiced within in by the local communities, for this reason it is worth analysing below the evolution of the concepts of the cultural landscapes which have been changing through the years.

\section{Cultural landscapes an irreducibility interaction of values}

Despite all the problems that humans have had to cope with nature, therefore the interplay between these two categories have not always been easy, nonetheless in some places of the world they finally reached some type of harmony with it, in fact some landscapes are considered sacred for a lot of communities spread around the globe and the relationship between each other have been maintained over the years. Furthermore, these kinds of relations are mostly intertwined and hence permeate the economic, social, ecological and geographical factors, which determine the continuous development of the landscape and its conservation in the time. Thus, if humans modify the world around them on an enormous scale, and have done so through co-evolutionary interactions for many thousands of years (Ellen, 1996), on what grounds a landscape might be regarded as cultural? If as I argued above every landscape around the world underwent a somewhat direct or indirect anthropic impact and transformation, whereby it might be said that all landscapes with which humans routinely interact are cultural (Ellen, 1996).

Following the assumption in which each landscape in the world it is to be understood as cultural, we are falling in a culturalist vortex where nature is a simple cultural construct, namely a universal object whose meaning depends on the cultural context. Nevertheless, considering a landscape simply as natural, hence mainly an object external to our domain and independent of our thought, we are still falling in another no less dangerous materialist vortex. Both way of conceptualizations of the landscape are naively trapped in the reductionist pitfalls of the vaunted simplistic naturalistic ontology, namely a cultural domain that is considered "particular" or "multicultural" and a natural "universal" or "mononaturalism" domain (Viveiros de Castro, 1998). In short, naturalism creates a specific ontological domain, a place of order and necessity where nothing happens without a reason or a cause (Descola, 1996), or in which certain things in nature owe their existence and development to a principle extraneous both to chance and to the effects of human will (Rosset, 1973). It seems that a naturalistic point of view, whether culturalist or materialist deploy the same stark culture-nature dualism whose reductionist approach could not help to understand the complex features of the cultural landscapes, where both nature and culture collide and conjoin in an interaction process which have been changed, maintained and enhanced over the time. However, it is plausible to analyse the evolution of the concept of cultural landscape and its main features, mainly for the importance of the values that this category encloses and strives to maintain nonetheless neoliberism and its consumerist-polluting society.

The term cultural landscape was introduced for the first time by the German Geographer Otto Schlüter in the early twentieth century and is him to whom is credited the first academic use of that term (James and Martin, 1981). It is worth noting that the word landscape, combines land with a verb of Germanic origin scapjan/schaffen, which means, literally, shaped lands. Lands were conceived as modelled by natural forces, and its shapes(s) in turn formed object(s) to be represented by landscape paintings 
(James and Martin, 1981). In 1908, Schlüter argued that by defining geography as Landschaftskunde (landscape science) geography would be given a thematic logic that does not exist in any other discipline (Elkins, 1989). Furthermore, the German geographer defined two forms of landscape: 1) the Urlandschaft (original landscape) or landscape that existed before human impacts and transformations, 2) and the Kulturlandschaft (cultural landscape), the landscape created by human culture. Thus, the principal task of geography was to track the changes in these two landscapes (James and Martin, 1981). As a result, the term "cultural landscape" has been a fundamental concept in geography and was formally defined as "landscape modified by human activity" by the German geographer Friedrich Ratzel in the 1890s (Jones, 2003).

According to these concepts, there is a neat distinction between a mere passive objective nature as the original landscape and the cultural landscape, hence transformed and created by human culture. Subsequently, it was the human geographer Carl O. Sauer who nonetheless endorsing a dualistic view of the landscape, it was him that in a more dedicated and influential manner, will promote and develop the idea of the cultural landscapes (James and Martin, 1981). Unlike the other authors cited, this human geographer went beyond in the analysis of the cultural landscapes, whereas for him the physical environment was a medium through which human culture acts, and therefore fostering the development, changing and rejuvenation of the landscape throughout the time and the pass of cultures (Sauer, 1925). Consequently, according to his famous concept: "the cultural landscape is fashioned from a natural landscape by a cultural group. Culture is the agent, the natural area the medium, the cultural landscape is the result" (Sauer, 1925). Nevertheless, some decades have passed since the ingenious and original concept coined by Sauer, it seems than even to date some international organizations such as UNESCO are still acknowledging willy-nilly the useful but nonetheless reductionist and dualistic view of a such complex category as cultural landscapes. In short, according to a somewhat trivial culture-nature dichotomy, cultural landscapes are cultural properties and represent the "combined works of nature and of man" (World Heritage Centre, 2008). Be that as it may, in 1992 The World Heritage Convention became the first international legal instrument to recognise and protect cultural landscapes (UNESCO, 1996).

Three categories of cultural landscapes are included in the World Heritage Convention: (1) "clearly defined landscapes designed and created intentionally by humans" this embraces garden and parkland landscapes, (2) "organically evolved landscapes" these results from an initial social, economic, administrative, and/or religious imperative and has developed its present form by association with and in response to its natural environment. (including "relict" and "continuing" landscapes), and (3) "associative cultural landscapes" that have powerful religious, artistic or cultural associations of the natural element rather than material cultural evidence, which may be insignificant or even absent (World Heritage Centre, 2008). It is evident to notice in these three categories of cultural landscapes, that humans modified the natural environment and adapted to it for sundry purposes, therefore it is a explicitly one-sided peaceful interaction between people and nature, namely the environment has been affected by anthropic activities, mostly of those activities were agricultural, architectural/aesthetic and most of them were related with sustainable land-use aspects and religious beliefs which provided a sustainable development and the enhancement of the natural and cultural values.

As far as these concepts might appear convincing to the reader, they are yet obscuring the two-sided interrelationships which exist between the people to whom the environment it is to be lived, perceived and above all provide the affordances (Gibson, 1979), that influence and shape the way in which each culture adjusts and interacts with its environment. Furthermore, the diverse ways of perception of the environment differ according to the interactions and taskscapes that each society develop over the time, namely the array of the tasks that people practiced and fostered being engaged in the activities of dwelling the landscape (Ingold, 1993). Thus, in the case of the saltpans, the salt worker who used to dwell and work in that environment have a very different and more profound perception than a tourist who only visit the site for a little while. For the former, the salpans represent the place where he interacts with his fellows, harvests the salt with traditional methods taught by his ancestors or older workers, feels the scorching sun of the summer, the smell of the sea, but mostly following Ingold (1993) he is connected with a landscape and "through living in it, the landscape becomes a part of him, just as he is a part of it", therefore to whom that cultural landscape is much more than place for leisure or to visit for a mere discounted tourist package bought in the website, for him this landscape it is to be understood as a complex interrelations of senses, hence only who is dwelling in that environment can understand what a cultural landscape really is. 
The perceptions and the relations which the people have with nature need to be taken seriously, otherwise the meaning of the cultural landscape will appear blurred if we only apply the clear-cut cartesian distinction that separates body-mind and nature-society. Perception in this sense is not the attainment of the mind in the body, but an organism as a whole in its environment (Gibson, 1979). As one of the classics in anthropology showed us, much of the relations between a so called "primitive" society and nature and its species (cattle), are intermingled in a continuum process of intimate interactions, thus for the Nuer of southern Sudan, cattle and men sustain life by their reciprocal services to one another in a real symbiotic relationship, moreover the harsh characteristics of the environmental system directly conditions Nuer life and influences their social structure (Evans-Pritchard, 1940).

At this point, it seems to me plausible to elucidate the complex features that deploy the western cultural landscapes of Sečovlje (Slovene Istria) and Janubio (Lanzarote), thus, both saltpans are located nearby mass tourism destinations and are facing the same problems such as: the lack of awareness of the importance of its resources by the territory, the salt market of the savage capitalism which threatens the conservation and continuity of the traditional activities of salt harvesting, and a tourism market which treat both saltpans and its values as a mere commodity to sell and indiscriminately exploit the precious resources of the whole human-environment relations. Hence, might the perceptions of other actors such as tourists differ from the perceptions of the salt workers about the saltpans? Could different stakeholders of both territories understand the complex relations that exist in a cultural landscape? Which kind of tourism in contrast to mass tourism would fit better in fostering the enhancement of the values of the satpans? These questions and those posed in the first part were asked to the informants of both territories, therefore focusing on the perceptions of the individuals involved in the saltpans about different issues related to the preservation and valorisation of the resources, as well as the impact of tourism. For these reasons, saltpans as a cultural landscape ought to be analysed and explored in the multidimensional interactions between humankind and nature without overlooking the phenomenological aspects that enclose each landscape and its dwellers. Before to discuss the analysis of the data, I will give a brief description bellow of the main features of both saltpans.

\section{The Sečovlje Salina Nature Park}

The (SSNP) represents a good example of a cultural landscape, indeed the society and nature are still maintaining the interplay between each other despite the different social, political, economic and geographical changes over the years. This park is situated on the Adriatic coast, at the mouth of the Dragonja River, in the southernmost stretch of the coastline of the Piran Bay. The Secovlje Salina, extended over $6,5 \mathrm{~km} 2$, is among the most important natural and cultural heritage sites in Slovenia, and therefore designated as the Nature Park, Ramsar Site, Natura 2000 site and a cultural monument of national importance (Sovinc, 2008).

The Park was proclaimed in 1990 by the municipality of Piran with the aim of preserving and enhancing the natural and cultural heritage of the territory and was protected by the State in 2001 with the Sečovlje Salina Nature Park law, accepted by the Slovenian Government. In short, the Park represents a great heritage for the whole Slovene Istria. The Sečovlje Salina Nature Park is the best example of an "open-air museum" in Slovenia, and could be considered as a major cultural resource that represents a genuine example of conservation and enhancement of the traditions of salt workers, where the heritage is the lifestyle and work of salt workers of past centuries ${ }^{1}$

The Park is divided in three protected areas (KPSS, 2011):

- the protected area that indicates the portion of the park called Lera, this is the part of the park where active salt production takes place;

- the protected area that indicates the portion of the park called Fontanigge;

- the protected area that indicates the part around the saltpans.

Lera includes 294 ha and is divided into an area for the crystallization and solidification of seawater. In this area salt is produced following the medieval tradition. Lera is characterized by animal and plant habitat delimited by different salinity salt fields, the canals and levees of saltpans. The area of Fontanigge includes 314 ha and is located in the middle of the Grand Canal and the Dragonja River (KPSS, 2011). Thanks to the exceptional ecological and cultural values, in 1993 Sečovlje Salina was designated Slovenia's first Ramsar Site (Škornik et al., 2004). 
The entire Sečovlje saltpans are considered as an ethnological, technological, historical and architectural heritage and landscape, both at and beyond the national level (Sovinc, 2012). Indeed, since 2004 are part of the European project called Natura 2000 (Vodeb, 2014).

The Strunjan and Sečovlje salt pans are unique on the eastern Adriatic coast in producing salt by means of an entirely traditional process which involves the daily gathering of the brine on the biosediment -the petola, which is an artificial grown crust that prevents the mixing of the salt and the sea mud on the bottom of the crystallization basin, and it functions as a biological filter (Sovinc, 2011). This method historically implemented exclusively in the space between Trieste and Pago, has been preserved only in these saltpans. This traditional method of production not only keeps the landscape characteristics of saltpans, but also helps to preserve the natural and cultural values of the area.

The cultural heritage of the Sečovlje saltpans includes (KPSS, 2011):

- The salt museum: the cultural historical monument protected at national level;

- The Sečovlje saltpans: the cultural historical monument;

- Sezza, Villa marittima, the peninsula of Sezza: registered archaeological site.

Figure 1: The Sečovlje Salina Nature Park

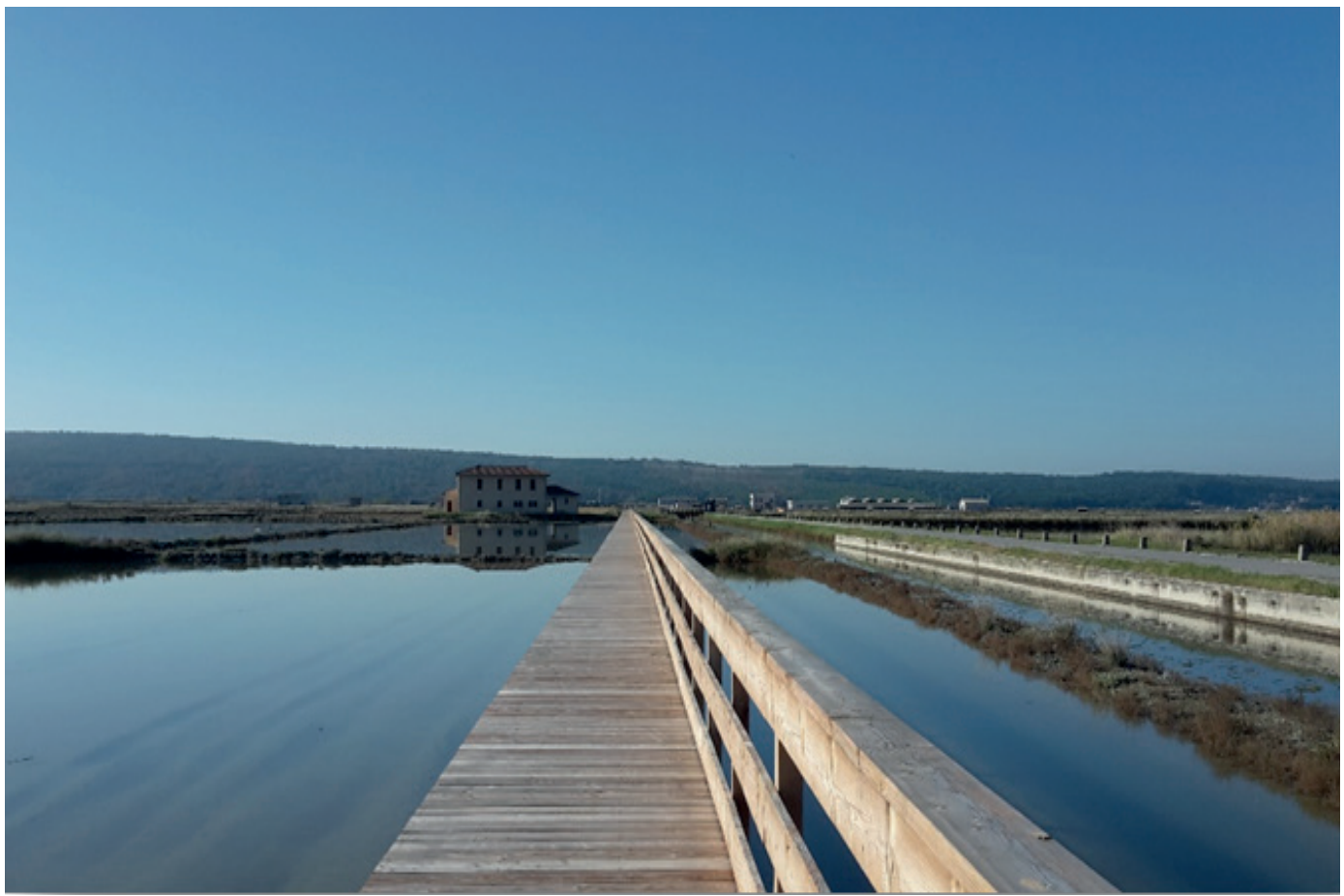

Source: by the author

In the park there are (under the rules of a protected area) developed several activities for tourists and other subjects: guided tours, workshops that allow people to appreciate and learn about the flora and fauna, various educational programs, some events (the traditional festival of salt workers), various sports and recreational activities (jogging, trekking, cycling), holistic activities (meditation, yoga and other activities for spiritual relaxation) exhibitions (ex tempore) and other activities. The park with its ecosystem is also the ideal place for research (KPSS, 2011). One important fact is the project called "Saltworks-Eco-touristic valorization of the Salt-pans between Italy and Slovenia 2007-2013", funded by the European Union which intended to enhance, protect and promote the Italian saltpans of Cervia and Comacchio and the Slovenian saltpans of Strunjan and Sečovlje ${ }^{2}$. 


\section{Site of scientific interest of Janubio}

The Janubio saltpans are located in the south west of Lanzarote in the Canary Islands and cover an area of 168,6 ha within the town of Yaiza ${ }^{3}$. The construction of these family run saltpans began in 1895 and finished in 1945, one of the most interesting facts about it, is the picturesque and peculiar landscape due to the Timanfaya eruption between 1730 and 1736 where the lava flows extremely modified the saltpans closing the old gulf and allowing the creation of the inner lagoon and the further creation of the saltpans ${ }^{4}$.

Thanks to its natural and cultural heritage, the saltpans since 1987 have been included in the Canary Islands Network for Protected Natural Areas (Red Canaria de Espacios Naturales Protegidos), first as a natural landscape and as site of scientific interest nowadays. Its norms of conservation were finally approved on July 20, 2006, by the (COTMAC), "Ordenación del Territorio y Medio Ambiente de Canarias", and published in the "Boletín Oficial de Canarias 27/2007". Furthermore, are integrated in the core zone of the Lanzarote Biosphere Reserve, which includes conservation and landscape maintenance as one of the great values that justified the declaration by UNESCO in 1993. The entire surface of the Site of Scientific Interest is considered as an area of environmental sensitivity ${ }^{5}$.

\section{Figure 2: Janubio saltpans}

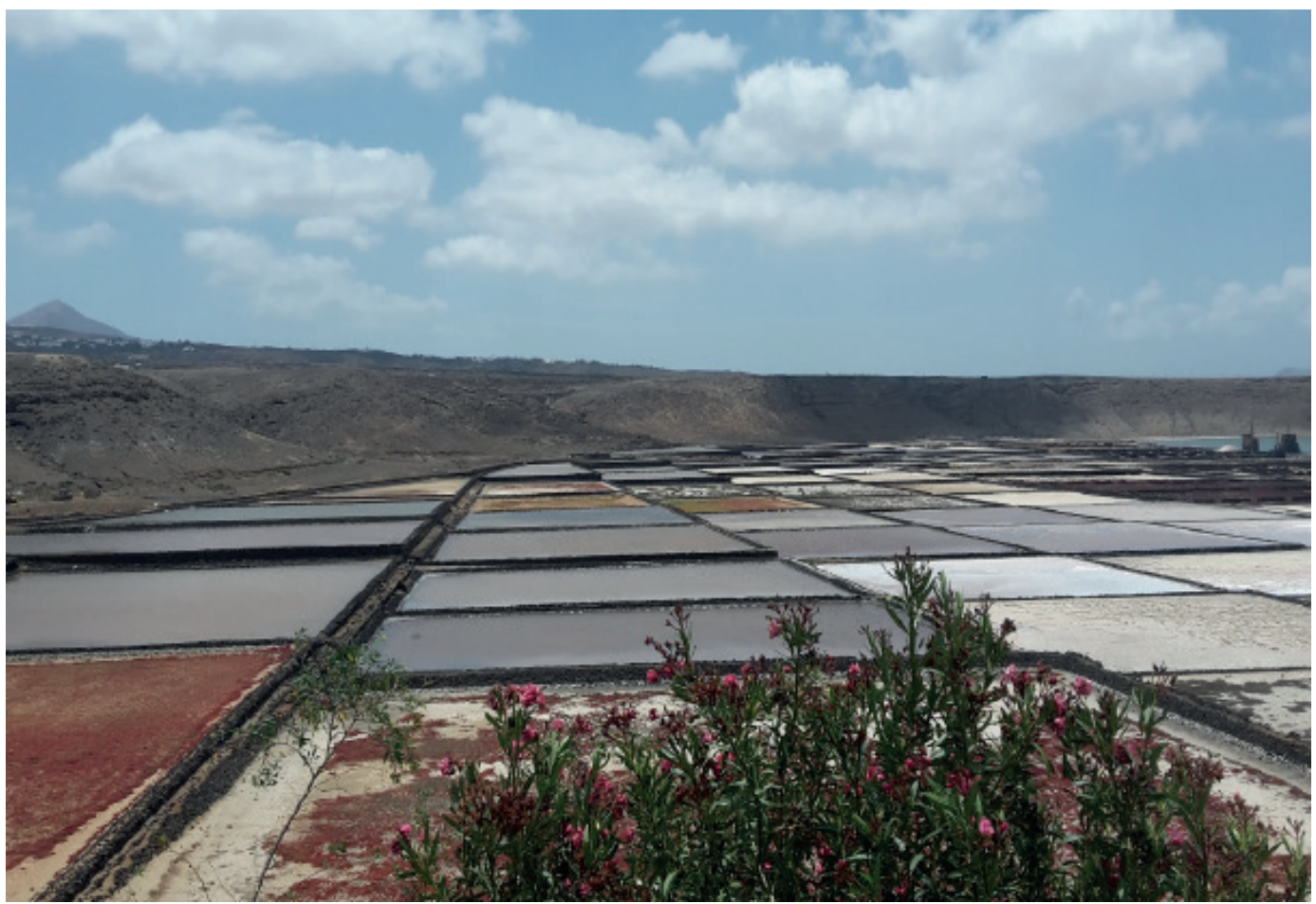

Source: by the author

In addition, Janubio saltpans have been declared International Bird Area (IBA), and special protection area (SPA), moreover are part of the Natura 2000 and Ramsar convention. One important fact is the wish of The International Union for Conservation of Nature and Natural Resources (IUCN) to include the Janubio saltpans in the red book of threatened landscapes. In fact, the saltpans own two declarations as a Site of Cultural Interest, one of them under the category of Monument and the other as a Paleontological zone. Subsequently, the Insular Planning of Lanzarote 1991, declared it "Sistema de Interés General del Medio Físico", and recommends to be equipped as a tourist attraction" 
Whereas, in 1990 the General Directorate of Environmental Quality of the Government of the Canary Islands undertook an initiative following the program of the develop of the outermost regions of the European Union "REGIS". In fact, the restoration of saltpans of the Canary Islands were the aim at that time. As a result, the pretention was to help the salt industry and improve the production and commercialization, as well as promote cultural tourism and ecotourism (Puche Riart et al., 2009).

Nevertheless, unlike the nearby El Carmen saltpans in Fuerteventura which have been restored completly, only a small part was restored in the Janubio saltpans (Puche Riart et al., 2009). Whereas, Janubio saltpans are the biggest and one of the most important saltpans in the islands, the contruction of a salt museum was an important objective long ago (Marín and Luengo, 1994). As a matter of fact, the project Centro Turístico Casa De La Sal, promoted by the Lanzarote Island Council and the so called Plan Futures ${ }^{7}$, was intended to enhance the natural and cultural values of the saltpans, building different facilities such as salt museum, interpretation center, viewpoint, paths and so on, mostly to provide sustainable deveopment in the territory ${ }^{8}$. Unfortunately, the idea has never taken place, despite being included in the Canary Islands Network for Protected Natural Areas (Red Canaria de Espacios Naturales Protegidos, ley 12/87), have been harmed due to the aggregate extraction. Nonetheless, these saltpans have been exploited since the $19^{\text {th }}$ century and still active nowadays (Puche Riart et al., 2009).

\section{Methods}

This study engaged 12 individuals involved in both saltpans ( $n=6$, in Sečovlje and $n=6$ in Janubio), a period of participant observation and in depth semi-structured interviews were conducted between September 2015 and April 2016. It is worth noting, that between these months I could carry out a somewhat deep ethnographic research in Sečovlje and its surrounding territories of Piran and Portorose where I have interviewed the informants, gathered the bibliography resources and mostly did the useful observations in the saltpans. I was fortunate to live and work in the tourism industry of the sea resort destination of Portorose for nearly 2 years, hence this permitted me to have enough time to carry out the research without facing some major inconvenient. Though the official language of this territory is Slovenian and my little knowledge of it, this was not a problem due to my knowledge of Italian, namely the second official language of the whole Istrian territory and in which most of the interviews were done, with the only exception of one interview that was done in English.

Unfortunately, unlike the time that I spent in Sečovlje, in the case of Janubio I was only able to stay in the field for merely one month (April 2016), therefore the time for fieldwork and interviews was evidently shorter. However, I tried to gather as much information as I could regarding the saltpans, thus, thanks to the interviews and observations made in Janubio and the nearby towns of Lanzarote I could obtain some important data concerning the objective of the research, and whereby the comparison between both cultural landscapes could be attained. Furthermore, in the case of Janubio the realization of the interviews was not an obstacle, thus due to my knowledge of Spanish as a mother tongue and English.

In addition, due to the topic and the phenomenological characteristics of the research, semi-structured interviews fitted better with the informants and they will to interpret they own point of view regarding the phenomenon. Semi-structured interviews are interviews that display a list of topics and questions to be discussed, sometimes without a defined order and, in most cases, without a precise formulation or canned responses (de Lillo, 2010). As a result, informants were selected for the interviews through a non-probability sampling, all the individuals who participated in the research are an important source of information for the analysis of this phenomenon, hence, they represent an objective sampling. In the objective sampling, sampling units are selected because they are in possession of aspects or particular characteristics which could better afford a careful exploration and understanding of the central themes and questions that the researcher will study (Ritchie et al., 2003). In short, the informants were individuals who work on the saltpans or in the tourism industry, therefore informants were first contacted by e-mail or telephone, or in some cases directly in they work places. Subsequently, interviews were carried out in offices or in one specific location agreed with the person to be interviewed and lasted roughly 45 minutes to one hour. All interviews were recorded and whereupon transcribed for the final analysis of the data, moreover due to the privacy issues interviewee names were replaced with the respective roles of the informants. Furthermore, the period of participant observation, though a bit short in Janubio, nonetheless was very useful to better understand the main features of the saltpans and hence to gather clues and information prior to the interviews, thus I could observe closer the life of the salt workers and the way in which they perceive and dwell the suggestive environment of the saltpans. 


\section{Results}

Results from the techniques of data collection were divided in three different key themes: 1) the awareness of the importance of the saltpans; 2) the enhancement of the values; and, 3) the benefits and impact of tourism. As I argued before, owed to the subjective characteristics of the interviews, it is worth emphasizing that the information given by the individuals was crucial to better explore the phenomenon. Indeed, informants tried to explain different peculiarities that ought not to be overlooked, and therefore the way in which they express their own perceptions about the importance of the values of the saltpans, differ among the people to whom the saltpans are a place in which they feel attached and connected, whether for diverse motives such as the awareness of the values that should be protected or for the different and profound relations that some people like the salt workers have with the natural environment, thus the majority of these perceptions contrast a lot with the way in which neoliberal activities such as mass tourism treat cultural landscapes and its important values.

In this respect, qualitative research and its methods specially ethnography in this case and the techniques of participant observation and semi-semi structured interviews which are part of it, are fitter to understand and interpret the social reality in depth, therefore reality cannot be observed or measured, but must be interpreted and understood (Weber, 2002). For this reason, cultural landscapes ought to be approached and analyzed in a way that the complex relations and different perceptions which exist in the territory be highlighted, thus unfolding the somewhat hidden nuances which otherwise will remain covert if the subjective perceptions of the informants were not considered. As one of the forefathers of anthropology clearly points out: "social anthropology studies societies as moral, or symbolic, systems and not as natural systems, that it is less interested in process than in design, and that it therefore seeks patterns and not laws, demonstrates consistency and not necessary relations between social activities, and interprets rather than explains" (Evans-Pritchard, 1951). I think this quotation could well be applied not only in anthropology but in all social sciences that want to better explore such a complex reality as the cultural landscapes.

\subsection{The awareness of the importance of the saltpans}

In the first key theme, informants were asked to describe their own conceptions about the importance of the saltpans and the different factors which undermine this awareness. During the interviews, I could discover some important cues about the neat difference in which some people approach to the cultural landscapes, hence, emphasizing the importance of the natural and cultural values that ought to be protected. The awareness for the protection of these values is in a stark contrast with a capitalistic logic of exploitation and mass consumption of the resources well known in sea resort destinations as both territories. As Ingold (1996) referring to the so-called rationalistic treatment of nature puts it: "Enlightenment thought has proclaimed the triumph of human reason over a recalcitrant nature. As a child of the Enlightenment, neoclassical economics developed as a science of human decision-making and its aggregate consequences, based on the premise that every individual act in the pursuit of rational self-interest". In short, either territories are a mass tourism destinations where natural environment has been modified, cementified and in the worst cases destroyed by the rationalistic logic of development, namely in these so-called sea resort destinations natural environment is a mere commodity to take advantage for the only purpose of earning as much money as possible, and therefore without thinking about the profound relations that some communities have with the not passive nature, and hence are extremely worthy of valuation.

The hedonistic features of most of the sea resorts give no room for a better appreciation of nature and its important role for the people who use to live within it and continue to engage hitherto in traditional activities. For example, since 2013 within the Sečovlje Salina Nature Park there is an open-air spa which offers wellness treatments using the natural resources of the saltpans. However, according to the interviewees the most wellness facilities of mass tourism nearby the saltpans consider a spa in the middle of a Natural Park as a competition, and therefore not a sustainable example to follow, thus, an individual who is the manager of the Park seemed worried about this situation:

"We don't want to compete with other wellness facilities... but unfortunately they see us as a competition and there's no real cooperation in the territory, in my opinion this represents an unfair competition that does not bring any benefit to the development of sustainable tourism in the area."

I1 (Manager, Sečovlje Salina Nature Park) 
In this instance, the lack of cooperation and awareness of the importance of the saltpans is evident, as a result, the informant argues that this kind of unfair competition doesn't provide any benefit to the saltpans and its resources. I can understand in his words that there is a problem about the cooperation in the territory, hence, it seems that most of the mass tourism facilities in the destination are worried about the services offered by the spa in the Park, namely this kind of unfair competition could harm the awareness of these resources and its important interactions of values.

As I argued before, I used to work in a resort located in the centre of Portorse within only few $\mathrm{km}$ from Sečovlje Salina Nature Park. During my observations, I could note that most tourists preferred to stay within the resort consuming all the all-inclusive services offered by it, such as pools, private beach, sauna and other wellness facilities that obviously used the resources of the saltpans for its wellness treatments. Indeed, salt, mud and brine were natural resources from the saltpans that these facilities tried to promote, nonetheless, though ironically only few tourists know about the existence of the saltpans and their location. It seems logic that this kind of promotion has nothing to do with the awareness of the importance of the saltpans, this is to say, the resort is only aware about the cost and benefits of the promotion and consumption of these resources, thus, as the I1 in a provocative manner puts it: "most tourists in the resorts preferred to be closed in the claustrophobic boxes of the wellness treatments, instead to be outdoor and feel better the natural environment of the territory". The wellness facilities promoted by the resorts are at odds with the open-spa located in the middle of the saltpans, indeed, the people who work in the Park explained me that all the materials used for the construction of the spa were natural resources of the environment, namely wood, mud, salt, brine and it is worth noting that this spa use merely solar energy and being opened only in the sunny days of summer.

This is the stark difference between a neoliberal logic of exploitation and commoditization of nature and the complex sustainable relations between human and nature in the cultural landscapes. According to the words of Christopher Tilley: "the neoliberal-capitalistic Western conception of landscape is that of a surface or volume like any other, open for exploitation and everywhere homogeneous in its potential exchange value for any particular project" (Tilley, 1994). This is the somewhat tragic situation of most of the mass tourism destinations, likewise the cultural landscapes which are located in the surroundings are increasingly threatened by this kind of logic of exploitation which try to encompass everything that could be sold and bought in the market for the mere sake of profit. Furthermore, due to the polluting activities promoted by mass tourism nearby both cultural landscapes, thus, it might be said that one of the main problems of the saltpans is the fragility of its environment, although Sečovlje saltpans have an outdoor spa, Janubio owns an astounding and almost surreal natural environment. Indeed, one informant explained how important are the Janubio saltpans in Lanzarote and for which reasons should be known and preserved:

"The most saltpans here in Lanzarote have disappeared over the centuries, and only Janubio remains active with the traditional salt harvesting methods. In my opinion, every person needs to know and be aware of the importance of these saltpans."

I9 (Tourist guide, Janubio saltpans)

According to her, Janubio being the last saltpans in Lanzarote ought to be known and conserved, in fact these saltpans are the most important in the entire Canary Islands. Subsequently, most informants were agreed about the fragility of both saltpans, indeed, Sečovlje and Janubio are the few remaining active saltpans in either territories, for this reason be aware about its importance seemed fundamental according to the respondents to provide a better conservation in time. In speaking about the preservation of the cultural landscapes Sven Arntzen points out: "cultural landscapes have an identity value and so are regarded as worthy of preservation because they provide meaning to people's lives and activities" (Arntzen, 2003). It is the word "meaning" that need to be understood as a way of attachment to a certain place or environment, although the tourist guide is a part of the tourism industry and hence neither used to dwell nor worked in the saltpans, this not prevent her to recognize the importance of the saltpans as a heritage of Lanzarote. This is the difference between a mere objective nature to exploit and a nature to whom some people endow with agency. In this sense, nature is not a basic category to only extract its resources, but it is more a "higher order" category (Rappaport, 1971) which permeate humans and is permeated by them in a relation of reciprocity. Thus, worthy to be protected cultural landscapes represent the irreducible values that are intermingled among the community and the environment. 
Furthermore, other tourist guide of the Sečovlje Salina Nature Park gave us a very important clue about the awareness of tourists of the importance of these resources, indeed she identified the types of visitors who are more aware and more interested in visit the saltpans:

"Tourists especially know about Sečovlje saltpans, but speaking about the awareness of its importance depends on the types of tourists. For example, hikers and those who want to spend their holidays in harmony with nature are mostly those that are more aware of the importance of the saltpans and the entire natural environment located on this territory."

I3 (Tourist guide, Sečovlje Salina Nature Park)

For this informant, tourists which are more aware of the importance of Sečovlje saltpans are mostly those who want to be in harmony with nature, thus, one might wonder if these types of visitors are better tourists than those who spend their holidays in the all-inclusive hotels? It seems obvious that the unsustainable way of approaching to nature is one of the main harmful features of mass tourism, that is to say, the commoditization and transformation of nature in gloomy and sterilized concrete buildings have produced a hyper consumption of a rather limited natural resources. Indeed, most tourists in these destinations are used to spend their time in these all-inclusive facilities, albeit with high costs that afford them to attain the so-called selfish pleasures of luxury and amusement.

Unlike those types of tourists, as far as I observed in the territory some hikers or adventure tourists are much more interested to be in the middle of the saltpans and therefore explore the nature and know more about the traditional activities of the salt workers. However, the motivations of the tourists to visit the saltpans may vary and depends on different factors and variables, nonetheless it is important to know the interpretations of the individuals to better understand the features of the visitors who are more interested in visit the saltpans. It reminds me an Italian backpacker who one day asked me which path would be better to follow to get to the saltpans, this fact surprised a bit, given that I was used to the usual very fashion clothed tourists that usually asked me only about how to get to the centre of Piran or to some fancy restaurant.

According to the philosopher Arne Næss: "It is highly necessary to promote a better valorisation of a more sustainable ecological approaches to nature which ensure the full richness and diversity of life-forms on the earth" (Næss, 1995b). For this reason, it is increasingly necessary the awareness of the importance of the values that the saltpans enclosed within it, hence certain activities such as tourism must be compatible with the preservation and valuation of the complex relations and resources that comprise the cultural landscapes.

Is it truth that both saltpans need to be protected to the harmful activities of mass tourism and other environmental degradations of capitalism, nonetheless this protection must be understood as the enhancement of the human-nature relations which the cultural landscapes used to deploy up to now, thus, the traditional activities of the saltpans ought to be carried on for a real valuation of the cultural landscape. In short, visitors who are really interested in the valorization of these resources need some information and a good accessibility to be more aware about the importance of the saltpans and know more of these protected areas. Unfortunately, according to the informant the lack of accessibility in Janubio represents a big problem to visit the saltpans:

"In my opinion, not many visitors know about the saltpans, because here in Lanzarote is a little bit difficult to get around without a car, given that public transport doesn't take you everywhere in the island. In fact, the accessibility of the Janubio saltpans is not good and for me is one of the main reasons which tourists don't know much about these saltpans and its important resources."

I9 (Tourist guide, Janubio saltpans)

I can confirm the words of the informant, thus, when I first arrived in Lanzarote the first thing that I asked was how to get to Janubio saltpans, I felt a bit disappointed when I discovered that the better way to arrive there was to rent a private car, therefore I discarded this option because I retained it expensive and useless if one wants to move freely without much worries about the parking. At this point it remained me only the last two options, namely a private tourist bus and a public bus, in the end I decided to try both options. In the former case the private bus took me to the most important towns and places in Lanzarote, It was a pity that the bus only stopped for few minutes in the saltpans and the most strikingly thing was that the passengers could not get off to better glance Janubio, in the latter case, the public bus left me in "la Hoya" stop nearby the saltpans, it is worth noting that the 
path to get from the stop to the saltpans was very harsh and neglected, indeed it was difficult for me to walk and finally take the first glance to the astounding landscape of Janubio.

Furthermore, for the whole time that I stayed in Lanzarote I could observe that Janubio saltpans are less known by the average tourist than Sečovlje saltpans, that is, most of the visitors prefer to visit other renown tourist's places in the island. It seems that the lack of a good accessibility in Janubio hinder the will to visit this cultural landscape, whereas most of the visitors are prone to rely on the private tourist's buses that abound in the main towns, and therefore only stop near the saltpans and the passengers can barely take some pictures. In short, during the informal conversations that I had with some tourists, I could realize that most of them are willing to visit other attractions nearby or simply do not know much about the saltpans and its important values.

In my opinion in both territories there is a not negligible problem of cooperation and awareness about the extremely importance of these cultural landscapes, that is, both saltpans represent the irreducible values of the interaction between culture and nature that have been carry on despite the noxious effects of the market activities. In this respect, Wang and Fu analyzing the cultural landscape of Jianan irrigation system in Taiwan baldly argue: "if the local people are lack of the identity and the necessary knowledge of the cultural landscape and cultural heritage, sometimes an irreversible damage to the cultural landscape would occur through the process of the public participation. The cooperation between local awareness and the academic researches would be important to avoid the degradation of the landscape" (Wang and Fu, 2011). It is this kind of cooperation that need to be fostered in both protected areas, not only for the sake of conservation as a museum can teach us, but it is the continuation of the traditional activities that represent the values of the cultural landscapes, and hence, the reciprocal relations of an active culture-nature collaboration (Plumwood, 2006) that need to be conserved, thus the awareness about the importance of these saltpans must be a priority.

\subsection{The enhancement of the values}

In this theme, the main issue was the discussion about the enhancement of the so-called natural and cultural values. As I discussed since the first part of the article, the distinction between these values ought not to be understood as a mere dichotomy, indeed in the case of the cultural landscapes though western, there is a complex and non-trivial relationship among nature and culture that must be foregrounded for a subtler exploration of these puzzling values. That is, one of the most interesting features of both saltpans is the traditional salt harvesting methods which have been undertaken to date, thus, the preservation of this intangible heritage seemed very important by the informants to better enhance the deep values of these cultural landscapes.

According to a neat culturalist approach characterized by the Boasian anthropology: "Human activities such as productive ones may produce culture and therefore incorporate cultural values" (Kroeber and Kluckhohn, 1952). In this sense, there is an overemphasizing of the cultural domain, that is to say, a mere cultural "appropriation of nature" (Ingold, 1986). The culturalist approach could not help us to consider the interrelations between humans and their "cultural activities" such as the salt harvesting methods and the non-human nature and all its species that dwell in it. "All things hang together" (Næss, 1989), and hence whichever activity undertaken by humans whether harmless as the cultural landscapes or harmful as the capitalist market will always confront to a nature with its own intentionality and not an inert object. The intangible heritage of the salt harvesting methods should be understood as a reciprocal fruitfully relations in which the salt workers have with the whole natural environment in which species with its own intentionalities dwell within it and not a mere tabula rasa to leave the imprint of the superior culture.

However, in the last years some saltpans around the world including Sečovlje and Janubio are suffering the consequences of the savage capitalism and its industrial mass production of salt. During my observations I could note a big concern in both saltpans about this fact that are indiscriminately forcing a lot of saltpans around the world to closed, let alone the very bad effects not only to the salt workers and their livelihood, but also to the fragile natural environment that remains exposed to the non-ethical way of treatment the nature by market capitalism. As a matter of fact, most of the interviewees retained that the traditional salt harvesting methods should be preserved and enhanced to a better conservation of the saltpans and its values. Thus, the manager of Sečovlje Salina Nature Park reiterated the importance to maintain the salt production with its traditional medieval methods: 
"I must emphasize that our goal was never to compete with the international market, as most people know it would have been much easier to produce salt in an industrial manner thinking obviously only to profit. However, we continue with a tradition of more than 700 years, our salt produced with these medieval methods is rich in minerals and is a sustainable product that enhances the natural and cultural heritage of the territory."

I1 (Manager, Sečovlje Salina Nature Park)

During the conversations with this informant was not hard to note his concerns about the plight of the saltpans that are facing nowadays due to the increasingly savage market of salt, therefore he argued that unlike other territories such as north Africa where the intensity of the sun is higher during the year and thus fitter for the industrial salt production, in the Istrian territory of Sečovlje, despite the less intensity of sun it will nonetheless continue with the traditional salt harvesting methods.

In short, it is worth noting how important is to maintain the traditional salt production to provide sustainability and a valuation of the resources, in contrast to the industrial methods and the international market which have always seen the "inert" nature as an object to exploit and tame for the only sake of take advantage of its resources, hence, without thinking about the preservation and the acknowledge of the complex values that the saltpans host. Furthermore, in the case of Janubio, for most of the informants the traditional salt harvesting methods are regarded as much important as in Sečovlje, moreover a salt worker who works for many years in the saltpans describes the importance of these traditional methods:

"We continue with a traditional salt production which obviously enhance the natural and cultural heritage. The harvesting method that we use does not harm the environment as the industrial methods."

I7 (Salt worker, Janubio saltpans)

Although Sečovlje saltpans are much bigger and the salt harvesting methods used are older than those used in Janubio, whereby in the former the traditional salt harvesting methods are medieval and those used in the latter dated from the beginning of the $20^{\text {th }}$ century. Notwithstanding, we need not deny the complex way of interactions and dwelling in the environment even in Janubio that the salt workers have used to foster so far. It is from this relational context of people's engagement with the world, in the business of dwelling, that each place draws its unique significance, namely, this means that in dwelling in the world, we do not act upon it, or do things to it; rather we move along with it (Ingold, 1993, 2000).

This is to say, that the natural environment of the saltpans is not an inert unmovable mass that only wait the action of human culture by its harvesting methods and the related activities of dwelling, moreover nature is not simply a medium in which human culture undertakes its practices as Sauer argued in his famous concept of cultural landscape. According to Val Plumwood, this concept of cultural landscape repeats the same Platonian-Aristotelian dualized and gendered conception between a rational-master principle and a formless-passive matter to be subdued, indeed she convincingly puts it:" with the father- 'culture' counted as sole agent, and the mother as the mere "medium" or 'nurse', the result, the 'cultural landscape', is naturalized as the child of this Aristotelian father as sole creator" (Plumwood, 2006).

Furthermore, the traditional salt harvesting methods of both saltpans ought to be regarded as not a sole cultural heritage which unwittingly underestimate the agency of the entire natural environment which participates in the cyclical processes of the so-called cultural production, but it is to be understood as a hybrid category in which diverse agencies are at stake. As a result, I can argue that in both protected areas the preservation of the traditional methods should be enhanced insofar the continue interplay of agencies not be downplayed as a mere cultural reductionism.

However, the preservation and enhancement of these values depends mostly on the cooperation in the territory, and therefore different projects should be undertaken to provide a better consciousness and valorization of these important resources. For instance, unlike Sečovlje saltpans which own a salt museum, interpretation center, spa and other facilities which represent a sort of valorization of the resources, in Janubio for many years exists a project called Centro Turístico Casa De La Sal, which was intended to build a salt museum and an interpretation center, nonetheless this project have never been taken place to date. Nevertheless, an informant who is an employee of the tourist office of Arrecife in Lanzarote told me that it seems that something it is going to change, indeed in these words she describes the current situation of the project: 
"The last time I talked with the person who is undertaking this project, he told me that the license to build the salt museum and the interpretation center is almost in the deadline, in fact he thinks that briefly those facilities will be built."

I10 (Tourist office, Janubio saltpans)

The undertaken of this ingenious project could evidently help to the enhancement of the whole values of the saltpans, moreover if this old project will take place someday will foster a better appreciation of the daily life of the salt workers and their deep relations with the natural environment which have been maintained through the time, thus, this will display to everyone the interrelations of values and intentionalities which are worthy of preservation. In this respect as Wang and Fu sharply point out: "the significant features of the cultural landscape were usually represented through the collective and numerous identical elements. Thus, the significant elements in the cultural landscape should be preserved and conserved with necessary legislative and technical instruments, to prevent or minimize the deterioration and change" (Wang and Fu, 2011). Consequently, the values that ought to be preserved and enhanced by the help of these facilities, represent the entire and irreducible heritage of this cultural landscape.

Talking about this holistic heritage that represents the human activities in a sort of harmony with the natural environment, thus, in Sečovlje the open-air spa "Thalasso Spa Lepa Vida" tries to promote and valorize the traditions of the salt workers employing the natural resources of the saltpans:

"The wooden structures resemble the salt workers houses where they could rest, these houses were built around the area of Lera by the Austro-Hungarian Empire and are still used for work and for rest of salt workers. The other main materials used for the construction of the spa were the stones and mud of the Sečoulje Salpans, all of which are natural materials from the Park to ensure sustainability and authenticity."

I1 (Manager, Sečovlje Salina Nature Park)

\section{Figure 3. Sečovlje saltpans, at the bottom Thalassso Lepa Vida spa}

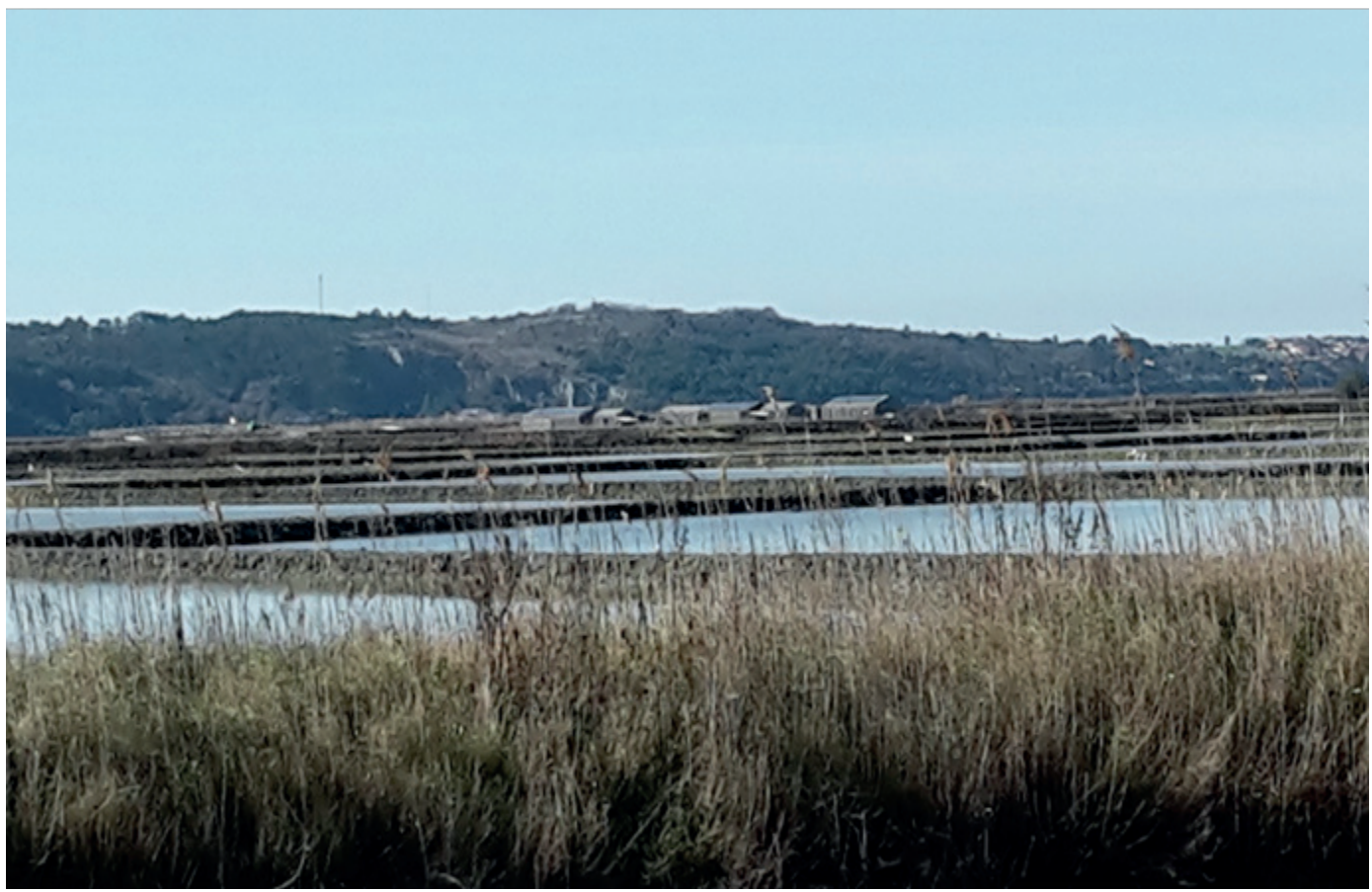

Source: by the author 
It is very interesting to see how the natural environment provides the resources to create some architectural and aesthetic structures like the spa located in the middle of the Sečovlje Salina Nature Park, nonetheless these are not to be understood as commodities which the only aim is to fulfil human needs, thus, this natural environment ought to be approached as a live organism with its own species, spaces and agencies, that is, as Descola and Pálsson emphasize: "some scholars have argued that the relations between organism and their environments are reciprocal, not one-way. In the process of engaging with the environment, organism construct their own niches" (Descola and Pálsson, 1996). The beforehand citation reminds me when I was roaming in the Sečovlje saltpans during a sultry day staring to the art of salt harvesting, suddenly a salt worker approached me and told me that near the spa nest very precious birds that he could recognize by their songs.

One of the outstanding features of human technical practices lies in their embeddedness in the current of sociality (Ingold, 1993), nevertheless this kind of sociality ought not to be considered as merely one-sided, namely emphasizing only the human domain and culture as the master of reason to whom nature is a separated ontological domain bereft with any kind of participation and intentionality. On the contrary this sociality could be regarded not only as two-sided, thus human-nature, but I think maybe there is perhaps room for a multi-sided sociality, that is, human agency and the manifold agencies of all organisms who dwell in the environment. In short, according to Ingold a dwelling is: "not a mere place of being, but a taskscape, an ensemble of mutually interlocking tasks that "come into being through movement" (Ingold, 2000). This is the way in which the salt workers dwell in their environment, therefore when they engage in the activity of salt harvesting they are in deep contact with other intentionalities of the natural environment that stimulate their senses and perceptions of what it is to "dwell". Thus, the complex relations between human and non-humans are one of the most important features of the cultural landscapes. Furthermore, the open-air spa could have a double function, the former as a health and wellness facility and the latter but the most important as a safeguard of the entire heritage of the site.

After all this analysis of the data of both territories, it might be said that the values of Sečovlje are more enhanced and promoted than those of Janubio, indeed, according to the interviews and the period of participant observation in the field, I could confirm this hypothesis. Nevertheless, it seems that the salt products of both protected areas are requested mostly by tourists, therefore one informant who works on the shop of the salt products of Sečovlje Salina Nature Park, argues that thank to these products the territory has become more recognized:

"These products are very popular among tourists, especially for foreigners. The first thing tourists want to do when they arrive in Piran is buy these products, I think thanks to the products of the Sečovlje Salpans, the territory and its resources have become much better known and appreciated in the world. Unfortunately, in my opinion there is no cooperation in the destination to enhance and promote the Sečoulje saltpans.”

I5 (Shop, Sečovlje Salina Nature Park)

It seems that the salt products of the saltpans are well known by tourists, thus, "Piranske soline" the official shops of the Sečovlje Salina Nature Park are well spread around Slovenia. This important fact could be regarded as sort of promotion of the resources of the saltpans, as well as a strategy to diffuse awareness of the importance of these values. However, the informant argues that there is no cooperation in the territory to enhance and promote these values, in fact the same problem has been highlighted in the first key theme, therefore it might be argued that the saltpans are not enough valued by the territory.

On the other hand, even in the case of Janubio it seems that the salt products sold in the traditional small warehouse of the saltpans are appreciated by tourists, thus, this informant recount about this fact:

"Some tourists buy the salt products and in my opinion, is very important that much more people recognize the benefits of the salt of the Janubio saltpans."

I10 (Tourist office, Janubio saltpans) 


\section{Figure 4: The entrance of the warehouse in Janubio}

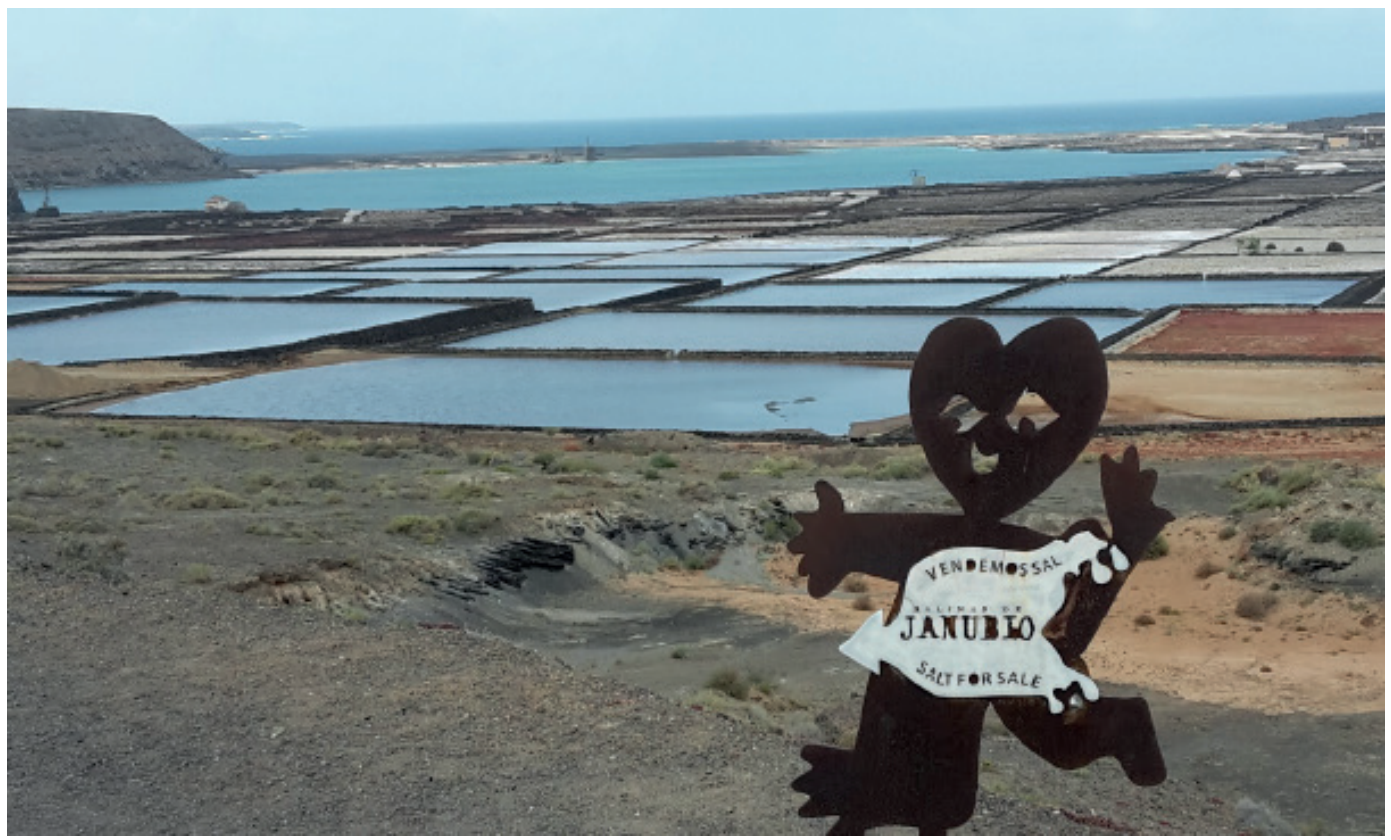

Source: by the author

During my fieldwork observations in both territories, I could appreciate that nonetheless the difference between the rustic small warehouse of Janubio and the "modern" and a bit fancy shops of Sečovlje and the surroundings, there is a connexon of values that either shops try to promote. These values are the core of the heritage of these saltpans, namely the salt products are not only the masterpieces of the salt workers who skillfully and elegantly defy the sun, mud, water, wind, birds, this is to say the "wild natural environment" that need to be domesticated and as a mere medium provides its precious resources for the attainment of the final products that will appear on the shelves of the shops ready to be consumed and appreciated by the visitors. It is these "enchantment technologies" (Gell, 1998) which are behind every grain of salt produced in these environments that bewitch the visitors, hence each bag of salt could be considered as the metonymy of the diverse types of agencies which belong not only to the salt workers and their masterful skills, but also to the whole natural environment and its organisms which are engaged in the entire processes and activities of these cultural landscapes.

Furthermore, it is worth noting that the rustic charm of the warehouse of Janubio could be an advantage due to its peculiar characteristics and moreover the undeniable breathtaking landscape of the saltpans. For these reasons, it is very important that both saltpans promote these values to keep alive the traditional salt harvesting methods and its astonishing holistic heritage.

\subsection{The benefits and impact of tourism}

In this final key theme, I will treat a somewhat paradoxical issue about tourism in the so-called protected areas, thus the saltpans discussed in this article are both areas characterized by the fragility of the natural environment, in this sense, two logics are at odds in this case, namely mass tourism and its harmful activities promoted mostly by the sea resort destinations and a rather environmentalist logic that most of the protected areas around the world strive to deploy. One example of this situation might have been given by Bacon and his case studies about the wetlands of Jamaica and Trinidad in the Caribbean, despite they have been seriously impacted by mass tourism, according to him: "wetlands could serve as a diversification of tourism industry. Where the natural heritage requires protection and tourism need to be monitored through the methodology of the various national environmental and socio-economic criteria for assessing the potential use of wetlands for these purposes" (Bacon, 1987). 
Far from being a neutral issue, the protection of the wetlands ought to be a high priority, but nonetheless different logics of nature collide, indeed, the harmful neoliberal activities of mass tourism which disrespect the natural environment and the radical conservationist logic that pretend to protect the so-called wilderness. The citation above seems to disregard the agency of nature and the relations that this has with the dwellers not the tourists of course, thus, nature is simply treated as an inoffensive prey that need to be protected from predators that are looking forward to hunting it and tear it to pieces. Regarding this matter, Descola points out: "by fetishizing nature as a transcendental object, the control of which would be displaced from predatory capitalism to the rational management of modern economics, the conservationist movements, far from questioning the foundations of western cosmology, tend rather to perpetuate the ontological dualism typical of modern ideology (Descola, 1996). Nevertheless, it is truth that the natural environment ought to be protected such as the case of the cultural landscapes, but this protection should not disregard the human and non-human relations who are at stake in these environments, thus, there is no need to hyper-separate nature and culture and represents nature as an absence of the human (Plumwood, 2006).

In both saltpans it seems that tourism is an important issue, and therefore according to the informants should be sustainable to not harm the fragile environment of them. As I described before, either protected areas are located nearby mass tourism destinations, hence, the most tourists are not much aware of these cultural landscapes and indeed are more likely to visit other tourist attractions in the territory. For example, it seems that the lack of accessibility is the main reason for this phenomenon:

"I proposed that an electric bus could bring tourists to the Park, it is true that we are close to the centre of Portorose but we are at the same time too far away for tourists who don't want to walk and go so far... but unfortunately there is no cooperation on this territory for the enhancement and promotion of the resources of Sečoulje. It would be much better if the hotels instead of offering chocolates to the visitors better offer a bag of salt as a souvenir and brand that enhance the territory."

I1 (Manager, Sečovlje Salina Nature Park)

Needless to say, that would be better if tourism would be monitored and therefore ought to follow the so-called pillars of sustainability to prevent any negative impact to the environment. Nevertheless, the somewhat utopian concept of sustainability needs to come to terms with the complex and reciprocal relations between humans and non-humans characterized by the cultural landscapes, thus, it might be said that both saltpans need conscious visitors that could foster the awareness about their important values. Furthermore, according to the informant an eco-friendly bus could be a good solution to invite visitors to the Sečovlje Salina Nature Park in a "sustainable" way, and therefore coping the lack of accessibility. In my opinion the powerful idea of sustainability needs to be less radical to acknowledge that environments such as cultural landscapes are far from being the Eden of nearly no human impact or a virgin pristine nature that should be fenced. For this reason, there is a need for a sustainability that aims to protect the interrelations among those humans and non-humans, that is the whole environment. In short, according to Arne Næss: "Most of the approaches to nature in the world could be compatible with nature, namely, only the Western approaches promoted by industrialized countries are against it" (Næss, 1995a). According to the clever idea of the informant, that is, of representing a bag of salt as a brand and souvenir of the territory to give to tourists, I think that this could be a strategy to enhance the resources of the saltpans and therefore to better improve the cooperation in the destination, namely, a seemingly frivolous bag of salt hides the collaborative and fruitfully interrelations between humans and non-humans which represent the core of the saltpans and moreover it is not merely the industrial salt bought in the supermarket.

As I could observe in the field, the accessibility of Janubio saltpans is worse than Sečovlje, this is probably due to the characteristic of the volcanic landscape which surrounds the entire environment. However, I could argue that nonetheless this situation some visitors visit the saltpans, though less than in Sečovlje, mostly by private transport. Furthermore, an American guy who works for some years as a tourist guide in one of the main private tourist buses led mostly by British, describes why visitors choose to take the tourist bus:

"As a tourist guide, I can argue that the people who decide to take our tourist bus want to know the most important tourist attractions in Lanzarote. In fact, we pass near the saltpans and explain them about it (but we don't stop it) ... I know that some tourists like to buy the salt products sold in the salt warehouse."

I8 (Tourist guide, Janubio saltpans) 
As I argued in the first key theme, Lanzarote is plenty of tourist buses which bring visitors to every corner of the island, indeed, there are different trips where you can explore the island form the north to the south visiting the most important tourist attractions. However, it is really a pity that these buses only stop for few minutes near the saltpans, and therefore as I described before you can't even get off to at least take a little glance and walk through the amazing colorful landscape of the saltpans. Furthermore, the informant told me that the tourist bus company does not allow to get off on the saltpans, nonetheless he gave me no motives for this decision, thus it seemed that perhaps he was unaware about this situation, therefore despite Janubio is located near to the most important tourist attractions of Lanzarote, such as Timanfaya National Park, el Golfo, Los Hervideros, Playa Blanca and the picturesque town of Yaiza it is impossible to visit Janubio by this type of transport, unless one rent a private car or rely to the slow and not efficient service of the public buses.

According to the interviews and the observations undertaken in the field, one might say that Sečovlje saltpans are more visited and appreciated than Janubio, nonetheless both protected areas are suffering the lack of accessibility which in either cases undermines the willing of the visitors to visit these cultural landscapes, and therefore to appreciate and acknowledge their important values. As I argued before, tourism should be compatible with the moral values of the cultural landscapes, that is, visitors ought to be aware that the natural environment of the saltpans is neither a mere commodity as a Luna park in which people have fun with the rides and peculiarities of the place, nor a zoo where visitors delight their trip watching some exotic animals that usually are treated as toys to take some selfies.

The deep values enclosed in these saltpans ought to be respected, and hence both territories have a moral commitment to foster campaigns about the awareness of the importance of these precious but threatened values, thus, to avoid any negative impact which could undermine the fragile environment and its holistic resources. In short, it might be argued that there is a need for a shift from the visitor perspective to the dweller perspective (Arntzen, 2003), to better esteem the complex non-dualistic interactions and integrations between humans and nature, moreover it is interesting to note that certain adventure tourists and hikers are rather close to the dweller perspective.

In analysing the problematic issue about the respect and awareness of the environment of the saltpans, one informant who also works inside the Sečovlje Salina Nature Park describes some of the visitor's behaviour and certain rules that they need to follow:

"There are also exceptions... some people are not aware of being inside a protected area and for this we are very careful to give information about the rules of behavior during their visit. For example, we explain that they must walk where there are marked paths and not to walk in the middle of the pools of salt. Unfortunately, sometimes there are people who do not follow certain rules, and therefore we have to remember them the appropriate behavior."

I5 (Shop, Sečovlje Salina Nature Park)

It is worth noting that during my frequent visits in these saltpans, it never happened to me to see a visitor polluting the environment or ill-behave, nonetheless according to the informant it seems that there are some visitors who do not respect the rules of the Park, and hence for this reason they need to remind them the appropriate behaviour, indeed, I could argue that the staff such as rangers works efficiently in Sečovlje, and therefore tourism is well managed and monitored.

Unfortunately, unlike Sečovlje, the manifold facilities which visitors evidently would need for a better visit and appreciation of the resources, are almost inexistent in Janubio, hence I can say that these saltpans are not well equipped for tourism. Thus, even if Janubio is much smaller than Sečovlje, and therefore cannot support too much visitors, nonetheless would be highly necessary to undertake the old project of the construction of the interpretation centre and the salt museum which could bring a better valuation of the deep values of the saltpans and therefore strengthen the awareness of their importance. Furthermore, as I argued in the first key theme, most of the paths inside the saltpans are neglected, thus, I think this is the main reason whereby it is difficult to walk through the colourful salt pools to better appreciate the art and skills of the salt workers and their way of engagement with nature. For these reasons, most of the visitors are more likely to take some pictures at the viewpoint located above the saltpans or otherwise buy some products in the warehouse. With these words, a salt worker explains what the most tourists do when they visit Janubio: 
"As you can see some tourists visit Janubio given the proximity to the Timanfaya National Park. They come here take some pictures and sometimes buy our products of the warehouse. In my opinion they really enjoy the environment and often they stop at the restaurant "Mirador de las salinas", which is located above the saltpans and where they can eat and mostly enjoy the amazing view of the saltpans."

I7 (Salt worker, Janubio saltpans)

The words of this salt worker reminds me a group of Japanese visitors who were taking some pictures in the viewpoint, this was a very warm sunny day and most of them were holding umbrellas and wearing caps, at some point they approached to the warehouse and bought a lot of salt bags to bring back home as a souvenir or perhaps for personal use, there, they only remained for few minutes and then immediately returned to their own transport without at least getting closer or walking through the paths. It seems obviously that maybe even for them, those black stony volcanic paths were difficult to get through, even if I think that this is the unique feature of this cultural landscape, nonetheless needs some care and a better maintenance, therefore a salt museum and the interpretation center could be the best thing to do for the enhancement of the entire values of the saltpans.

Nevertheless, the building of these facilities are to be understood not as a petrification or suspension in the time like the museum does with its artworks, hence, the traditional activities of the cultural landscape ought to be carry on to foster a real valorization of the complex relations between human culture and non-human nature, that is, as Ingold points out: "the activities that comprise the taskcape are unending, the landscape is never complete: neither "build" nor "unbuild", it is perpetually under construction (Ingold, 1993). In my opinion, the somewhat cyclical and never-ending process of interrelations between humans and nature represent the main core and complexity of the so-called cultural landscapes.

In addition, even if Se ovlje saltpans are much more visited and are better positioned as a tourist attraction than Janubio, nonetheless Janubio saltpans are located near to the Timanfaya National Park and others tourist attractions of Lanzarote, hence, I think this could be an advantage for the future sustainable tourism development in the territory, inasmuch that this respect and acknowledge the precious values of this cultural landscape.

\section{Conclusion}

The puzzling nature-culture dichotomy has been well discussed in the field of humanities so far, this peculiar abstraction of the natural domain into a universal brute object to whom the master cultural domain acts as an absolute civilized tyrant, remains a bottomless vortex in which has been difficult to emancipate it, thus, this western naturalistic ontology represents an unsurmountable hurdle which prevent us to have a better appreciation of nature and its non-human dwellers, moreover the complex relations that humans have with them. As Marshall Sahlins points out regarding this western dualism: "As enchanted as our universe may still be, it is also still ordered by a distinction of culture and nature that is evident to virtually no one else but ourselves" (Sahlins, 2008). It is this way of conceptualization of nature and its submission with culture that I have tried to challenge in this article, hence, I have tried to suggest that ecological anthropology is well fit and in a good position to overcome this reductionist dualism, therefore emphasizing the interactions between a human culture permeated and influenced by a non-passive nature and a nature or non-human domain, being influenced as well, in a cyclical process of continuous interactions.

As I have shown here, cultural landscapes are an interesting category in which the nature-culture relations ought not to be neglected, this is to say, they need to be approached and analysed by the useful tools of ethnographic research. For a better understanding of the complexity of the values which are enclosed in the cultural landscapes, one must consider the people who live within in and the way which they perceive and interact with the environment, thus, talking with them and live close to their environment could better help the analysis of these complex but astounding relations that people have with nature. Furthermore, cultural landscapes are a place where different agencies are at stake, namely they are to be understood as cultural, as well as natural, inasmuch humans and non-humans intentionalities not be obscured or merely naturalizing or culturalizing it. For these reasons, cultural landscapes might be better called "collaborative" or "interactive" landscapes (Plumwood, 2006), that is, collaboration and interaction are the most important features that need to be maintained and preserved for the sake of all living and non-living beings.

The saltpans of Sečovlje located in the upper Adriatic and Janubio in Macaronesia in the North Atlantic Ocean are interesting examples of western cultural landscapes where the continuity of human 
and nature interactions is still present nonetheless capitalism and its harmful activities. However, future research needs to be done to better understand if the complex heritage of these cultural landscapes is enhanced or not by both territories, therefore whether a somewhat sustainable and respectful tourism could fit well for the appreciation and acknowledge of the values of these saltpans. As I argued in this article, some important clues I could obtain during my fieldwork observations, nonetheless this was not enough owed to the short period of fieldwork undertaken in Janubio that undermined the comparison of both saltpans and therefore the scope of the research.

Nevertheless these issues, I have tried the best as I could to demonstrate that even in a western context, the complexity of the cultural landscapes like the saltpans of Sečovlje and Janubio should be highlighted and not downplayed for a better valuation of their precious values, thus, in enhancing the holistic values of human and non-human relations these saltpans will continue to foster the collaboration and interaction of culture and nature that has been the core and the life of these cultural landscapes. In short, both territories have the pledge to promote the awareness about these invaluable resources, hence, unlike the neoliberal logic of consumerism and mass tourism which deprive nature with its importance for all living and non-living beings, that is, backgrounding the agency of each organism who dwell in the environment, I have hope that perhaps there is a room for a more ethical, moral and sustainable tourism which would recognize the importance of the natural environment and its manifold intentionalities who always has been interacting with humans and their cultures, thus, forming complex and continuous relations such as the cultural landscapes that are worthy of preservation.

\section{Bibliography}

Århem, K.

1990. "Ecosofía makuna". In La selva humanizada: ecología alternativa en el trópico húmedo colombiano

(ed.) F. Correa, 106-26. Instituto Colombiano de Antropología. Bogotá.

Arntzen, S.

2003. Cultural Landscape and Approaches to Nature - Ecophilosophical Perspectives. Norway: Telemark University Collage.

Bacon, P. R.

1987. Use of wetlands for tourism in the insular Caribbean. Annals of Tourism Research, 14 (1): 104-117. de Lillo, A.

2010. Il mondo della ricerca qualitativa. UTET Università.

Descola, P.

1992. "Societies of nature and the nature of society". In Conceptualizing societies (ed.) A. Kuper, 107-26.

London: Routledge.

Descola, P.

1994. In the Society of Nature: A native ecology in Amazonia. Cambridge: Cambridge University Press. Descola, P.

1996. "Constructing natures: Symbolic ecology and social practice". In Nature and society: Anthropological perspectives (eds.) Descola, Philippe \& Gísli Pálsson, 82-102. London/New York: Routledge.

Descola, P. and Pálsson, G.

1996. "Introduction". In Nature and society: Anthropological perspectives (eds.) Descola, Philippe \&

Gísli Pálsson, 1-21. London/New York: Routledge.

Elkins, T.H.

1989. "Human and Regional Geography in the German-speaking lands in the first forty years of the

Twentieth Century". In Reflections on Richard Hartshorne's The nature of geography (eds.) Entriken,

J. Nicholas \& Brunn, Stanley D, 27. Occasional publications of the Association of the American

Geographers, Washington DC.

Ellen, R.

1996. "Introduction". In Redefining nature. Ecology, culture and domestication (eds.) R. Ellen and K.

Fukui, 1-36. Oxford: Berg.

Evans-Pritchard, E. E.

1940. The Nuer. Oxford: Oxford University Press.

Evans-Pritchard, E. E.

1951. Social Anthropology. New York: Free Press. 
Gell, A.

1998. Art and Agency: an anthropological theory. Oxford: Clarendon.

Gibson, J.

1979. The Ecological Approach to Visual Perception. Boston: Houghton Mifflin.

Godelier, M.

1984. The Mental and the Material: Thought, Economy and Society (M. Thom, trans.). London: Verso.

Heidegger, M.

1962. Being and Time, trans. MacQuarrie and Robinson, New york: Harper and Row.

Heidegger, M.

1971. Poetry, language, thought. New York, NY: Harper.

Howell, S.

1984. Society and Cosmos: Chewong of Peninsular Malaysia, Chicago and London: University of Chicago Press.

Ingold, T.

1986. The appropriation of nature: Essays in human ecology and social relations. Manchester: Manchester University Press.

Ingold, T.

1992. "Culture and the Perception of the Environment", In Bush Base-Forest Farm: Culture, Environment and Development (eds.) E. Croll and D. Parkins, London: Routledge.

Ingold, T.

1993. The Temporality of the Landscape. World Archaeology, 25 (2): 24-174.

Ingold, T.

1996. "The optimal forager and economic man". In Nature and society: Anthropological perspectives

(eds.) Descola, Philippe \& Gísli Pálsson, 25-44. London/New York: Routledge.

Ingold, T.

2000. The perception of the Environment. Essays in livelihood, dwelling and skill. London: Routledge. James, P.E. \& Martin, G.

1981. All Possible Worlds: A History of Geographical Ideas. New York: John Wiley \& Sons.

Jones, M.

2003. "The concept of cultural landscape: discourse and narratives". In Landscape Interfaces: Cultural

Heritage in Changing Landscapes (eds.) Palang, Hannes and Fry, Gary,21-51. Dordrecht: Kluwer.

Kareiva P, Watts S, McDonald R, Boucher T.

2007. Domesticated nature: shaping landscapes and ecosystems for human welfare. Science 316(5833):18661869.

Karim, W.-J.

1981. Ma'Batisek concepts of living things, London: Athlone.

KPSS.

2011. Krajinski park Secoveljske soline - Nacrt upravljanja 2011 - 2021.

Kroeber, A. L. and Kluckhohn, C.

1952. Culture: A Critical Review of Concepts and Definitions, Harvard University Peabody Museum of

American Archeology and Ethnology Papers 47.

Lévi-Strauss, C.

1962. Le Totémisme Aujourd'hui. Paris: PUF.

Luengo, A y Marín, C.

1994. El Jardín de la sal. Ed. Excmo. Cabildo Insular de Lanzarote. Cfr.184-185

y 225.

Marx, K.

1994. Selected writings (eds.) Lawrence H. Simpson. Indianapolis \& Cambridge: Hackett Publishing Company.

Næss, A.

1989. Ecology, Community and Lifestyle. Cambridge, New York: Cambridge University Press.

Næss, A.

1995a. "The Third World, Wilderness, and Deep Ecology". In Deep Ecology for the Twenty-First Century. (ed.) George Sessions, 397-408. Boston, London: Shambhala.

Næss, A.

1995b. "Deep Ecology for the Twenty-Second Century". In Deep Ecology for the Twenty-First Century. (ed.) George Sessions, 463-468. Boston, London: Shambhala. 
Plumwood, V.

2006. The concept of a cultural landscape. Ethics and the Environment, 11/2.

Puche Riart, Octavio; Ayarzagüena Sanz, Mariano y Mazadiego Martínez, Luis Felipe.

2009. Patrimonio salinero español. En: „La aportación histórica de la sal: investigación y puesta en valor“. Memorias de la Sociedad Española de Historia de la Arqueología (II). (ed.) Sociedad Española de Historia de la Arqueología (SEHA), 103-120. Toledo. ISBN 978-84-692-4848-5.

Rappaport, R.

1968. Pig for the Ancestors: Ritual in the Ecology of a New Guinea People, New Haven: Yale University Press.

Rappaport, R.

1971. Ritual, Sanctity and Cybernetics. American Anthropologist 73: 73-76.

Rappaport, R.

1979. Ecology, Meaning and Religion, Berkeley: North Atlantic Books.

Reichel-Dolmatoff, G.

1971. Amazonian Cosmos: The Sexual and Religious Symbolism of the Tukano Indians, Chicago:

University of Chicago Press.

Ritchie, J. \& Lewis, J.

2003. Qualitative research practice. A Guide for Social Science Students and Researchers, London: Sage Publications.

Rosset, C.

1973. L'anti-nature: Eléments pour une Philosophie Tragique, Paris : Presses Universitaires de France. Sahlins, M.

2008. The Western Illusion of Human Nature: With Reflections on the Long History of Hierarchy, Equality and the Sublimation of Anarchy in the West, and Comparative Notes on Other Conceptions of the Human Condition, Chicago: Prickly Paradigm Press.

Sauer, C.

1925. The Morphology of Landscape. University of California Publications in Geography, 22: 19-53.

Searle, J.

1995. The Construction of Social Reality, London: Allen Lane.

Seeger, A.

1981. Nature and Society in Central Brazil, Cambridge: Harvard University Press.

Škornik, I., Sovinc, A., Gogala, A.

2004. Sečoulje Salina Nature Park, CD-ROM, Soline Co. Ltd.

Sovinc, A.

2008. Secovlje Salina Nature Park, Slovenia - new business model for preservation of wetlands at risk.

Global NEST Journal, Vol 11, No 1, pp 19-23, 2009.

Sovinc, A.

2011. Sečovlje Salina Nature Park, Slovenia: Latest development and important cultural activities. In: Papayannis, T., Pritchard, D.: Culture and Wetlands in the Mediterranean: an Evolving Story. Athens, Med-INA, 227-234.

Sovinc, A.

2012. Assessment of the use values of the Sečovlje Salina Nature Park (Slovenia). Annales: Series Historia Naturalis 22.2 (2012): 189-196.

Strathern, M.

1980. "No nature, no culture: the Hagen case". In Nature, culture and gender (eds.) Mac Cormack and M. Strathern, 174-222. Cambridge: Cambridge University Press.

T i 1 l e y, Christopher.

1994. A Phenomenology of Landscape. Places, Paths and Monuments. Oxford: Berg Publishers.

UNESCO (United Nations Educational S, and Cultural Organization) (1996) Operational guidelines for the implementation of the world heritage convention. UNESCO, Paris. http://whc.unesco.org/ archive/opguide05-annex3-en.pdf

Viveiros de Castro, E.

1998. "Cosmological deixis and Amerindian perspectivism." Journal of the Royal Anthropological Institute 4 (3): 469-88.

Vodeb, K.

2014. Trajnostni razvoj turisticnih destinacij alpsko - jadranskega prostora. University of Primorska. 
Wang, Chun-Hsi and Fu, Chao-Ching.

2011. The Sustainable Development of the Cultural Landscape of Jianan Irrigation System in Taiwan. Presented at the ICOMOS 17th General Assembly and Scientific Symposium, Paris, France.

Weber, M.

2002 "Economy and Society: An Outline of Interpretive Sociology". In Readings in Economic Sociology (ed). N. W. Biggart, Blackwell Publishers Ltd, Oxford, UK.

World Heritage Centre.

2008. Operational Guidelines for the Implementation of the World Heritage Convention. Paris: UNESCO World Heritage Centre.

\section{Notas}

Dedi. Secoveljske soline. (Retrieved from: http://www.dedi.si/dediscina/430-secoveljske-soline, accessed 17, October 2015)

2 Cooperazione territoriale europea programma per la cooperazione transfortaliera Italia Slovenia. (Retrieved from: http:// www.itaslo.eu/projects/projects_2007_2013/2012110811544976, accessed 8, January 2016)

3 Gobierno de Canarias Consejería de Medio Ambiente y Ordenación Territorial Dirección General de Ordenación del Territorio. (2006). Normas de conservación del sitio de interés científico del Janubio.

4 Salinas de Janubio. Historia. (Retrieved from: http://www.salinasdejanubio.com/historia.html, accessed 10, March 2016)

5 Salinas de Janubio. Medioambiente. (Retrieved from: http://www.salinasdejanubio.com/medioambiente.html, accessed 10, March 2016)

6 See reference above.

7 Plan Marco de Competitividad del Turismo Español, better known as Plan Futures, was a Spanish plan launched 13, November 1991 to help and fund different touristic projects and activities in the country.

8 Plan Futures Ministerio de Industria, Comercio y Turismo Secretaria General de Turismo Promotor Cabildo Insular de Lanzarote. (1993). Proyecto de Demostración Centro Turístico Casa de la Sal Salinas de Janubio, Yaiza, Lanzarote, Canarias. 